\title{
ESTADO SECURITÁRIO, DIREITO PENAL DO INIMIGO E A SEGURANÇA COMO RAZÃO DE SER DO ESTADO
}

\author{
Fernando Vidal Brito ${ }^{1}$
}

RESUMO: O punitivismo moderno e o estado constante de vigilância na sociedade moderna encontram raízes teóricas nas correntes punitivistas da jusfilosofia penal que acumula séculos de tradição. A noção do homem como lobo que é predador do homem é tradição antiga que influencia a corrente punitivista e defende que a razão fundamental do Estado é garantir a segurança daqueles que estão sobre a umbrela do Estado. Tal cenário levou a construção de um estado securitário no qual a segurança é o valor supremo, influenciando as relações pessoais e erguendo e derrubando governos, assim como auxiliando na construção do Direito Penal do Inimigo. $O$ presente artigo buscará demonstrar as raízes desse contexto e como correntes naturalistas nefastas se fazem presentes por meio da construção de um inimigo a ser destruído.

Palavras-chave: Punitivismo. lei. Inimigo. Segurança. Jakobs.

ABSTRACT: Modern punitivism and the constant state of vigilance in modern society find theoretical roots in the punitivist currents of penal jusphilosophy that accumulate centuries of tradition. The notion of man as a wolf that is a predator of man is an old tradition that influences the punitive movement and defends that the fundamental reason of the State is to guarantee the safety of those who are under the umbrella of the State. Such a scenario led to the construction of a security state in which security is the supreme value, influencing personal relationships and raising and overthrowing governments, as well as helping in the construction of the Enemy's Criminal Law. This article will seek to demonstrate the roots of this context and how harmful naturalistic currents are present through the construction of an enemy to be destroyed.

Keywords: Punitivism. Law. Enemy. Safety. Jakobs.

\section{INTRODUÇÃO}

O Estado atual enfrenta uma crise no qual o poder punitivo rompe com o estado de direito e acarreta um cenário que relembra os tempos do absolutismo. $\mathrm{O}$ estado de direito que foi fundado em seu primeiro momento sobre a umbrela de um

' Mestrando em Filosofia na UFES e graduado em direito na UFF.E-mail: vidalfernando@live.com 
estado liberal que defendia a abstenção do Estado sobre a esfera do indivíduo está ruindo e o próprio motivo de ser do Estado pouco é associado à liberdade, mas sim à segurança e a necessidade de se proteger do lobo que é o homem. Nesse contexto surge o estado securitário que vigia a todos e pune a todos. Eleições, relações familiares, políticas, culturais e até mesmo o modo de vida são influenciadas pela segurança como valor político supremo.

A segurança alimenta o medo e a paranoia, assim como aumenta o clamor por mais punições e ações mais incisivas por parte do Estado contra o crime, levando à criação das chamadas guerras ao crime organizado que se manifestam de inúmeras formas. Porém, o cenário atual é uma nova roupagem para velhas figuras da eterna luta entre garantismo e punitivismo. A luta travada que se revela no cenário atual do estado securitário é a eterna luta entre segurança e liberdade, entre direitos e deveres.

A segurança como valor político supremo justifica muitas ações daqueles que comandam o poder e servem o propósito de reintroduzir com um estilo mais atualizado as teses mais nefastas da tradição punitivista. Portanto, o presente trabalho se propõe a discutir o estado securitário, assim como suas consequências e como esse é instrumentalizado para perpetuação de projetos de poder autoritários.

Por último, o presente trabalho buscará demonstrar as cruéis raízes naturalistas que ainda permanecem no discurso punitivista e como esse influencia grandemente nas políticas de segurança pública, assim como auxiliam a construção de um "inimigo" sobre o qual está absolutamente permitido o uso de toda força do martelo da lei.

\section{ESTADO SECURITÁRIO: INSTRUMENTO E CONSEQUÊNCIA}

A segurança como valor político supremo e motivo fundante para a formação do Estado, tal qual defendem punitivistas do século XX, como Gunther Jakobs, acabou por formar o Estado Securitário, um ente capaz de materializar pesadelos distópicos e de oprimir e suprimir liberdades e garantias individuais. Mas o que exatamente é o Estado Securitário? Como ele é consequência de uma política punitivista e ao mesmo tempo instrumento gerador dessa política? Quais as 
consequências desse Estado e quais as causas que permitiram a criação desse leviatã? Indiscutivelmente, segurança e liberdade são assuntos relacionados e difíceis de serem abrangidos em uma mesma umbrela sem um ameaçar o outro. A história política e do próprio estado alterna entre segurança e liberdade, onde um é valorizado em detrimento do outro. Em um estado securitário, no qual a razão de ser é a própria segurança, a liberdade se torna um valor precário ameaçado de extinção a qualquer momento. O Estado de Direito é um muro de proteção que busca proteger a liberdade de forma a impedir que a busca pela segurança, seja ela física, econômica ou política, fira as liberdades individuais. A democracia liberal foi fundada sob esse preceito de que as garantias individuais operariam como um obstáculo ao totalitarismo, não podendo existir liberdade sem garantismo, ou seja, a ideia do liberalismo clássico francês do século XVIII imprescinde de limites ao poder estatal, perdendo sua razão de ser sem esse muro protetivo. (ZAFFARONI, 2017, p. 33-44)

É irônico que em terrae brasilis, autodenominados liberais e defensores da democracia lutem arduamente contra o garantismo penal, utilizando chavões populistas para defender a tese de que "a lei protege bandidos". A lei não protege bandidos, ou não deveria proteger, ao contrário do que os defensores do punitivismo que visam atacar o garantismo penal pregam. Ela protege o próprio tecido social cada vez mais fragilizado pelas medidas tomadas em "nome da segurança". Esse é o grande problema da jusfilosofia do século XXI e que mais tem enfraquecido o Estado de Direito. A utilização genérica de "razões de segurança" como justificativa para supressão de direitos individuais. Em nome da segurança se justifica a utilização de mandados de busca em domícilio de forma coletiva, em nome da segurança se justifica supressão de etapas processuais, em nome da segurança se justifica a supressão do direito fundamental de ir e vir sem o cumprimento dos requisitos em lei, gerando uma superpopulação carcerária. A segurança não é mais apenas um valor buscado individualmente ou coletivamente para preservação da vida, mas sim é um modo de viver que reflete nas interações sociais, políticas, econômicas e principalmente na forma que o Estado se apresenta. A segurança se tornou um motivo de existir e assim deu origem ao denominado "Estado Securitário". (AGAMBEM, 1995, p. 12). 
É notório que a segurança como razão de ser para a formação da sociedade humana - e consequentemente do Estado - não é uma novidade na jusfilosofia. A ideia de que o homem é o lobo do homem é uma ideia antiga na filosofia e defendida sobre a justificativa de que o homem em estado de natureza vive uma situação de guerra constante, sempre sujeito a matar ou morrer e que por isso a formação da sociedade humana se dá com o objetivo principal de proteção, de obter segurança contra o próximo. (HOBBES, 2014, p. I03). O estado securitário é então consequência da eleição da segurança como valor político e moral supremo, todas as escolhas dentro de um Estado sendo baseadas na manutenção ou obtenção da segurança acabam gerando um estado securitário. Porém, o estado securitário é também um instrumento de propagação da ideia da segurança como bem supremo, é um sistema que se retroalimenta e altera as relações humanas de outrora.

A democracia representativa e os meios de difusão em massa possuem um papel chave em tal cenário distópico de opressão de liberdades individuais. A sensação de medo e insegurança acaba por dar força a discursos populistas, gerando uma sensação de insegurança constante que acaba alterando as relações humanas e sendo fator fundamental para decisão dos rumos da "democracia". Candidatos são eleitos sob a plataforma da segurança, de que é necessário fazer o possível para que essa seja alcançada, mesmo que alguns direitos tenham que ser suprimidos para isso. A coletividade, como cordeiros correndo para o abatedouro, acaba abraçando esses discursos populistas, em grande parte por serem condicionados diariamente a uma sensação de insegurança que geralmente não corresponde à realidade dos fatos. (ZAFFARONI, 2017, p. 64).

A classe política promete mais punições, menos garantias, um combate mais "duro" e recebem o apoio popular por meio das eleições, concedendo mais poderes punitivos que são usados para propagação de agendas de interesses das classes sociais que apoiam o discurso punitivista. Beneficiados pela democracia representativa que limita a partição direta do povo, os políticos são emponderados com poderes sob a vida privada dos cidadãos, podendo usar esses poderes não para garantir a segurança como o pregado, mas sim visando a perpetuação no poder. As infames guerras ao terror, guerra às drogas, guerra à corrupção e tantas outras são travadas como 
plataforma para promoção política, acabando por reforçar a sensação de insegurança e aumentar o clamor por mais segurança. Se estamos em um cenário de guerra o que é excessivo para alcançar a paz? Nessa lógica securitária, muito pouco. A liberdade individual sofre com isso e o Estado de Direito mingua cada vez mais frente a sanha totalitária dos punitivistas. (CONDE, 2012, p.2)

Até mesmo aqueles que deveriam operar dentro dos limites da lei, visando cumprir o papel não apenas de aplicá-la visando o caso concreto, mas também os valores institucionais e o simbolismo nela representado, acabam usando para promoção da própria carreira, seja para ascensão dentro do próprio ramo judiciário ou então como campanha política populista visando cargos eletivos. Essa é uma realidade antiga, em especial no Estados Unidos da América. A tradição secular do país de norte-americano do carreirismo de membros do ramo judiciário faz-se presente em todos os níveis da administração. A atual vice-presidente americana, a ex-senadora Kamala Harris era promotora de justiça que utilizou da sua carreira como promotora para promoção da sua plataforma política, apresentando um histórico de condenações preocupante e que demonstra o hiperpunitivismo moderno, com um altíssimo índice de encarceramento preventivo por crimes de baixo potencial ofensivo e principalmente concentrados nas camadas mais desfavorecidas da sociedade norte americana ${ }^{2}$.

O uso de uma agenda punitivista para promoção pessoal supera barreiras partidárias, alcançando os dois espectros da política estadunidense. Outro membro notório da política americana, o ex-prefeito de Nova Iorque, Rudy Giulliani, também ascendeu politicamente por meio da plataforma punitivista, ainda nos tempos de procurador geral e como advogado do distrito do sul de Nova Iorque, adotando uma política de tolerância zero, defendendo punição pelas menores infrações como forma de inibir a criminalidade, reforçando tal política punitivista durante seu período como prefeito da maior cidade do país norte-americano e alcançando tamanha

\footnotetext{
${ }^{2}$ LOPEZ, German. Kamala Harris's controversial record on criminal justice, explained, U.S.A, I2 de set de 2019. Disponível em: https://www.vox.com/future-perfect/2019/r/23/18184192/kamala-harrispresident-campaign-criminal-justice-record> Acesso em o6 de dez de 2020
} 
projeção política ao ponto de ser nomeado com o título de cavaleiro honorário pela coroa inglesa ${ }^{3}$.

A plataforma política da tolerância zero de Rudy Giulliani e a teoria que a baseava, "Teoria das janelas quebradas", ultrapassou barreiras, alcançando especialmente a América Latina, onde o "Prefeito da América", como é conhecido o político estadunidense, passou a receber fortunas para dar palestras sobre a necessidade do escalonamento das punições e da atividade policial, defendendo o punitivismo exacerbado como forma de combate ao crime, contribuindo para a cultura da guerra ao crime existente no continente. (ZAFFARONI, 2017, p.63-64)

Entretanto, não apenas o punitivismo estadunidense foi importado, mas também a essência do carreirismo político de membros do poder judiciário e das forças militares. As eleições brasileiras de 2018 configuram um grande exemplo da ascensão do discurso punitivista e da plataforma da segurança pública como valor político supremo, tendo em vista que o número de policiais e militares eleitos para o poder legislativo quadriplicou em relação ao pleito de 2014 $4^{4}$. O presidente eleito no mesmo pleito de 2018 foi eleito como uma das suas principais plataformas a segurança pública, prometendo varrer o "inimigo" e travar uma guerra contra a corrupção estatal. No Estado do Rio de Janeiro, um juiz federal foi eleito governador com a promessa de que no governo dele a polícia teria autorização para executar criminosos, promessa essa que cumpriu, tendo até registro em vídeo do mesmo indivíduo comemorando uma operação que resultou na morte de um sequestrador como se fosse um gol de futebol's. Vale ressaltar que não pretendo aqui julgar a necessidade da utilização da força letal no caso concreto, tendo em vista que não possuo especialidade em situações de refém, mas sim pretendo demonstrar o caráter

3 SILVERMAN, Stephen. Queen Elizabeth knights Rudy Giulliani, U.S.A, I3 de fev de 2002. Disponível em: 〈http://www.people.com/people/article/o,,623496,oo.html〉Acesso em o4 de abril de 2021.

${ }^{4}$ GELAPE, Lucas. Número de policiais e militares no Legislativo é quatro vezes maior do que o de 2014. Rio de Janeiro/RJ, o8 de out de 2018. Disponível em: <https://gi.globo.com/politica/eleicoes/2018/eleicao-em-numeros/noticia/2018/10/o8/numero-depoliciais-e-militares-no-legislativo-e-quatro-vezes-maior-do-que-o-de-2014.ghtml> Acesso em o4 de abr de 2021

5 GLOBO Gr. Sequestro na ponte: Witzel comemora desfecho e diz que familiar de criminoso pediu desculpas. Rio de Janeiro/RJ, 20 de ago de 2019. Disponível em: 〈https://gr.globo.com/rj/rio-dejaneiro/noticia/2019/o8/20/governador-do-rj-diz-que-prioridade-e-protecao-de-refens-em-sequestrode-onibus.ghtml> Acesso em 03 de abr de 2021. 
nefasto do governador afastado, afastado por corrupção que prometeu combater, ao celebrar a morte como uma vitória de um time de futebol. Por sinal, o governador afastado é um exemplo da utilização da carreira judiciária para fins de promoção política, algo que de forma alguma se limita a ele, tendo em vista que membros de inúmeras forças tarefas se apresentam como potenciais presidenciáveis ou possíveis candidatos a outros cargos eletivos, na última década, até mesmo ministros do STF foram cogitados como potenciais presidenciáveis, demonstrando a influência da tradição estadunidense de ascensão política de membros do judiciário com a utilização do combate ao crime como principal plataforma política.

É importante adicionar, que o hiperpunitivismo no Brasil, assim como nos Estados Unidos da América, ultrapassa toda e qualquer barreira política, afetando ambos os lados do espectro político, tendo em vista que nos catorze anos dos governos de esquerda o número de operações armadas em comunidades carentes multiplicou exponencialmente, em especial no Estado do Rio de Janeiro com apoio do governo federal e até mesmo auxílio das forças de segurança nacional e do Exército Brasileiro, fator que contribuiu para algo comparável à um genocídio das camadas mais pobres do país, demonstrando que não há inocentes na classe política, estando todos com as mãos sujas do sangue derramado na chamada "guerra ao crime" 6. A segurança como valor político supremo ultrapassou ideologia, não há possiblidade de eleição com tal tema não sendo protagonista, não importando o nível da disputa eleitoral e nem a orientação partidária dos candidatos envolvidos, esse é o valor supremo, o motivo que elege governos, assim como os derruba. Obviamente não apenas a segurança pública coopera para isso, o clamor por segurança na economia e na própria política geram o clima atual, cooperando para o Estado Securitário atual que alterou profundamente as relações sociais.

Historicamente, as relações sociais se baseiam na confiança mútua, apenas assim é possível a existência de instituições do direito civil como o condomínio, casamento e os contratos comerciais. No princípio da confiança que um indivíduo se

\footnotetext{
${ }^{6}$ Gi, Globo. Dilma assina permissão para Exército atuar no Conjunto de Favelas da Maré. Rio de Janeiro/RJ, 29/o3/2014. Disponível em: 〈http://gi.globo.com/rio-de-janeiro/noticia/2014/o3/dilmaassina-permissao-para-exercito-atuar-no-conjunto-de-favelas-da-mare.html> Acesso em 28 de mar de 2021.
} 
permite morar em um condomínio de apartamentos com menos de I metro separando as portas da residência entre condôminos, apenas pela confiança um indivíduo se sujeita a sentar em uma barbearia e permitir o barbeiro manusear uma lâmina afiada em seu pescoço. Sem a confiança no próximo, as relações passam a ser regidas pelo medo, a segurança passa ser a prioridade, levando ao auto encarceramento em casas com muros grandiosos reforçados com cercas elétricas e sistemas de segurança aprimorados. Esse medo, essa desconfiança leva a criação de inimigos, inimigos esses apontados por aqueles que utilizam da segurança pública como forma de ataque ao Estado de Direito e como ferramenta para avanço de agendas autoritárias e para perpetuação no poder ainda que essa perpetuação no poder não se concretiza por um golpe, mas sim pelo voto na pretensa democracia que é a expressão máxima da democracia representativa.

Por isso, o Estado Securitário cria inimigos a serem combatidos, inimigos que justificam o aumento do Estado Securitário, o aumento do poder punitivo do Estado e a redução de direitos e garantias individuais. A criação do inimigo é o cerne de qualquer corrente punitivista, sem inimigos a serem destruídos não há a possiblidade de mobilização das forças políticas em prol do punitivismo e por isso um Estado Policial ou um Estado Securitário imprescinde de um grupo a ser destruído ou combatido e esse é o maior perigo do Estado Securitário, pois ele depende de um inimigo a ser destruído para existir, mas também os cria para se ampliar ou permanecer existindo. Por isso, não há como continuar o tema sem trabalhar o histórico dos inimigos eleitos pelo punitivismo ou sem debater quem são os inimigos perseguidos no cenário do punitivismo brasileiro.

\section{IDENTIFICAÇÃO DO INIMIGO}

O punitivismo não pode sobreviver sem um inimigo definido, aquele pelo qual se justifica a possibilidade da ação punitiva fora dos limites legais e que sirva para a retórica política de aumento do estado securitário. O Estados Unidos da América encontrou no início do milênio o terrorismo como grande inimigo, o alvo a ser destruído e que servia como base a instauração de um estado policial e a definição de medidas como o ato patriota, utilizando os meios para espionar a própria 
população, fato que levou às revelações trazidas por Edward Snowden, ex-agente da espionagem estadunidense ${ }^{7}$. Tal identificação do terrorismo como inimigo a ser destruído levou à consequências sociais graves, com a identificação de certos grupos como potenciais delinquentes, mas esse assunto será tratado em momento posterior, já que é necessário debater também a questão nacional. No Brasil, foi no tráfico de drogas que o punitivismo encontrou um alvo a ser combatido e destruído. A guerra às drogas consome grande parte dos esforços da segurança pública nacional, assim como domina o debate público e político, sendo pauta central de qualquer projeto de governo. A guerra às drogas assim como a guerra ao terror, gerou um grupo específico que por características sociais ou naturais inerentes se tornou alvo da perseguição do aparato policial e do poder punitivo estatal, porém, em ambos os casos a questão vai muito além dos valores jurídicos que são feridos pelos crimes de tráfico de drogas e terrorismo, mas sim passam por questões jusfilosóficas e criminológicas seculares cujo influência determinista e discriminatória ainda são muito presentes.

A criminologia que visa a identificação de um inimigo inerentemente perigoso, ou seja, de um indivíduo propenso ao crime por questões naturais, é antiga, possuindo raízes nas mais nefastas correntes punitivistas do século XX e com forte racismo influenciando tais tentativas de identificação ôntica do inimigo. As teorias lombrosianas e garofalianas podem parecer uma memória distante para alguns, mas elas ainda são muito presentes no imaginário punitivista e político. Essas teorias buscavam coroar um inimigo que não era passível de ressocialização, um inimigo que por sua própria natureza estava sempre passível de cometer crimes e romper o contrato social, criminosos de nascença cujo única solução era o extermínio. As formas de identificar esse inimigo variavam, e ainda variam, de acordo com o criminologista adepto do inimigo ôntico, às vezes essa identificação se dava por características cranianas, outras vezes por características fenotípicas como cor dos olhos, pele ou gênero e muitas vezes por questões sociais. Essas teorias fazem parte da corrente do positivismo criminológica, mãe do punitivismo moderno, defendendo que o criminoso, aquele que rompe costumeiramente o pacto social, faz por ser da sua

7 Gi, Globo. Dilma assina permissão para Exército atuar no Conjunto de Favelas da Maré. Rio de Janeiro/RJ, 02/o7/2013. Disponível em: <http://gi.globo.com/mundo/noticia/2013/o7/entenda-ocaso-de-edward-snowden-que-revelou-espionagem-dos-eua.html> Acesso em 22 de mar de 2021. 
natureza, um ser incapaz de agir de forma diferente e por isso devendo ser tratado como inimigo a ser destruído. (ZAFFARONI, 2017, p. 9I)

Observe que a conclusão dos positivistas criminológicos defensores do inimigo ôntico é muito similar a do punitivista moderno como a de Jakobs, diferenciando-se apenas na justificação explicita, isto é, na justificação externada ao público, porém é muito perceptível que a influência naturalista do positivismo criminológico persiste ainda hoje e para isso é necessário que se observe o que definia um “criminoso nato" passível de destruição na corrente do positivismo criminológico. A principal característica dessa mudança de paradigmas foi a inserção da punição preventiva, das medidas policiais que se antecipam ao crime. Se alguns cidadãos são naturalmente inclinados ao ato de delinquir, logo é justificável se tomar medidas antecipatórios, estabelecendo vigilância constante nesses certos grupos e até mesmo prisões temporárias e de caráter precário. (ZAFFARONI, 2017, p. 93)

O positivismo se posicionava contra os "inimigos naturais da sociedade" (GAROFALO, 20I0, p. II) e a aplicação a estes do mesmo direito reservado aos "cidadãos de bem" configuraria traição do povo, nesse mesmo sentido defendia que para o volkisch o Estado de Direito com suas tradicionais garantias era utilizado para defender criminosos e não o povo e a sociedade. (ZAFFARONI, 2017, p.93-95). É notório como o debate público não mudou em relação ao tema de segurança pública, pois ainda hoje há uma clara polarização entre "nós”, pessoas de "bem”, e “eles", criminosos incapazes de recuperação e por isso merecedores da destruição, estando o Estado de Direito no meio de tal agrupamento oposicional sendo acusado pelos punitivistas de "proteger vagabundos" e atacado por garantistas de se demonstrar fraco em garantir os direitos individuais previstos na própria fundação do Estado de Direito. O que se adapta é o inimigo, na Alemanha hitlerista o inimigo era a comunidade judia que era tratada como parasitária e responsável pelas mazelas da nação alemã, nos Estados Unidos da América a partir dos atentados de II de setembro de 20oI, a comunidade vista como uma inimiga a ser combatida foi a comunidade árabe em geral, em especial os que professam a fé islâmica, já no Brasil nas últimas três décadas em especial, os inimigos são os que vivem marginalizados nas periferias da grande cidade não sendo tratados como cidadãos tanto no aspecto de segurança 
policial, mas também no aspecto de bem-estar social do Estado não recebendo a devida assistência de saúde, de saneamento ou educação, estando as periferias em grande parte completamente desprovidas da presença do Estado. Pensadores como Franz Von Liszt defendiam que:

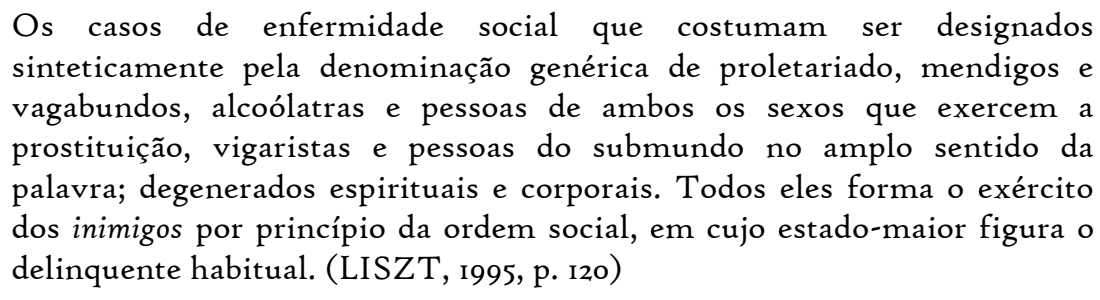

O delinquente na visão ôntica do inimigo é inferior moralmente, socialmente e biologicamente. Essa visão pode parecer datada depois dos horrores das grandes guerras mundiais, mas o punitivismo atual que alimenta o Estado Securitário ainda defende e nutre tais pensamentos, em especial nos agentes políticos. Tomemos como exemplo o ex-governador do Rio de Janeiro como exemplo, que em entrevista aos meios de comunicação se referiu às mulheres de periferias marginalizadas como "fábricas de bandidos". ${ }^{8}$

No discurso desse ex-governador fica clara a influência da Escola Positiva e como o punitivismo moderno - especialmente no Brasil - não adota apenas o elemento político e o agrupamento amigo-inimigo como definição do inimigo, mas também há o velho racismo e preconceito da Escola Positiva que enxerga em determinados grupos étnicos ou sociais uma inferioridade genética, uma predisposição ao crime. Não apenas isso, enxerga-se os grupos marginalizados da sociedade como alguém sem livre-arbítrio que necessariamente cairá na marginalidade, pois a vontade desses é irrelevante. Esse discurso de propensão ao crime legitima a atuação policial violenta e abusiva, assim como legitimava a atuação nos regimes autoritários do século XX que adotaram a figura do delinquente ontológico. $\mathrm{O}$ inimigo não é mais visto apenas como o inimigo político da sociedade, mas também como o inimigo natural da sociedade. (GAROFALO, 2005, p. 7) Da mesma forma, no ordenamento jurídico nacional, o Direito Penal do Inimigo não atua somente por razões políticas, mas

\footnotetext{
${ }^{8}$ Cabral apoia aborto e diz que favela é fábrica de marginal. Folha de São Paulo., São Paulo, 25 de out de 2007. Disponível em: < https://wwwi.folha.uol.com.br/fsp/cotidian/ff251020070r.html> Acesso em o3 de dez de 2019
} 
também por razões "naturais". A população pobre e marginalizada entra no conceito de inimigo não apenas político, mas também o natural, devido a crença de que esses são propensos ao crime e que são "fábricas de marginais". Garofalo afirmava que "mediante uma matança no campo de batalha a nação se defende de seus inimigos externos; mediante uma execução capital, de seus inimigos internos". O que vemos no Estado Brasileiro se não uma guerra contra os "inimigos internos"? Os inimigos não são apenas os criminosos graves que se opõe a própria ordem jurídica - como Jakobs define o inimigo - mas também os indesejáveis, aqueles vistos como desnecessários pelo poder político. (ZAFFARONI, 2018, p. 94)

Por medo desse inimigo justifica-se o aumento do Estado e para combater esse “inimigo repugnante" se ataca o Estado de Direito, pelo medo desse inimigo criado amplia-se o estado securitário que por sua vez trabalha por meio de discursos políticos e por plataformas políticas eleitoreiras e oportunistas para aumentar a sensação de insegurança e o medo, criando assim um ciclo infinito de insegurança que permite com que o autoritarismo avance cada vez mais sobre a esfera dos direitos individuais. Portanto, a figura criada de um “inimigo" é essencialmente política, mas não se limita a isso, pois há também o elemento geneticista que enxerga nos grupos marginalizados inferioridade e periculosidade. A figura do delinquente habitual possuiu extrema relevância também no estado nazista, gerando a lei nazista de 1933 tratando do assunto da delinquência habitual. (LASCANO, 2004, p. 179) A antiga lei de criminalização da mendicância que vigorava no ordenamento jurídico nacional também demonstra a influência do punitivismo e da Escola Positiva de identificação ontológica do "delinquente nato" no Brasil. A criminalização da pobreza não é novidade do século XXI, apenas voltou a ser "moda”.

O inimigo não se manifesta apenas por ato de poder político, mas sim da sua própria existência, o saber e o conhecimento são colocados a disposição do poder político e o inimigo se revela por si próprio, por ser quem ele é. O inimigo logo é aquele marginalizado que vive nas periferias ou talvez alguém com conduta diversa da considerada a conduta de um "bom cidadão". Logo, o elemento político e o biológico na escolha do inimigo se confundem e se alimentam, gerando uma arbitrariedade política ainda maior do que a da decisão política fundamental, pois o 
inimigo não é inimigo apenas por decisões políticas, mas sim pela "ciência". A pena desproporcional ao ato cometido, ou seja, a pena retributiva que recai sobre o autor não devido ao ato criminoso, mas sim ao delinquente se justifica devido à “delinquência habitual”. A pena ou a medida de segurança é aplicada ao inimigo não pela sua conduta culpável, mas pelo seu "ser culpável”. Vale ressaltar que no Estado nazista a perseguição aos judeus não se dava somente por uma suposta inferioridade genética, mas também sobre um mito da traição dos judeus à pátria alemã, sendo esse mito da traição dos judeus um estereótipo herdado de séculos de antissemitismo que se fortaleceu e adquiriu o aspecto político/étnico principalmente após o período da revolução francesa - anteriormente a perseguição aos judeus era predominantemente por questões religiosas - que gerou as já famosas consequências de um dos períodos mais sombrios da história humana.

O Direito Penal do Inimigo, mesmo que se baseie nas razões de segurança do Estado ou na decisão política fundamental de oposição a outro, surge a partir dessa manifestação de dois direitos distintos, um ao cidadão comum que é considerado igual e outro ao estranho, ao inimigo. Ao estrangeiro, pobre, marginalizado e outros tipos indesejados pela sociedade se aplica o Direito Penal do Inimigo, ao igual, ao amigo, o direito aplicado é o direito constitucional com todas as suas garantias fundamentais, tudo baseado na "periculosidade" do autor e é claro, nas razões de segurança, a razão de ser do Estado punitivista moderno. A segurança do Estado era inclusive a motivação expressa da Escola Positiva e havia a defesa firme da redução de garantias individuais que se colocassem contra o pro societatis, havendo também a inserção da expressão "guerra contra o delito" no debate jusfilosófico, dois conceitos muito similares ao Direito Penal do Inimigo, (ANITUA, 2008, p. 313).

Logo, teorias como o Direito Penal do Inimigo de Jakobs, as teorias de identificação do inimigo de Lombroso e Garofalo, assim como o conceito de político de Schmitt são influências vitais para a mentalidade punitivista atual que domina o círculo político e contribuam para o crescimento de um estado policial em serviço de um estado securitário. Por isso, a última parte do presente artigo buscará demonstrar como o cenário geral do Estado Securitário acaba criando um fardo para o próprio 
sentido do estado de direito e como a situação atual revela a fragilidade que causa o perigo de extinção do estado de direito, pelo menos da forma que o conhecemos hoje.

\section{MATERIALIZAÇÃO DO ESTADO SECURITÁRIO E A PERSEGUIÇÃO AO INIMIGO}

Como já trabalhado no artigo, o Estado Securitário e o punitivismo necessitam da figura do inimigo como justificativa para o aumento do poder punitivo por “razões de segurança”. Para tanto, o inimigo eleito é tratado não como cidadão, mas sim como um inimigo que está sujeito à um direito flexibilizado e secundário, no qual as garantias e direitos individuais e processuais não são integralmente aplicadas. $\mathrm{O}$ inimigo eleito no Brasil é todo aquele que faz parte das camadas mais populares da sociedade, aqueles que moram nas comunidades periféricas e são apontados como inimigos em potencial devido à declarada "guerra às drogas". Há a criminalização não de um fato, mas de um sujeito, de um indivíduo, de um grupo inteiro de pessoas por simplesmente existirem conforme uma noção pré-concebida discriminatória e persecutória. Porém, essa perseguição não se limita apenas em discurso político ou eleitoreiro, como o discurso do ex-governador do Rio de Janeiro que afirmava que mulheres de comunidade eram "fábricas de bandido", mas sim em ações reais que demonstram a existência de um direito único a ser aplicado a todo aquele que é visto como inimigo. Essas ações tomadas em nome da "segurança" escancaram a existência de dois direitos distintos. Tomemos como exemplo o direito à inviolabilidade do domicílio. Pelo ordenamento jurídico nacional, o domicílio é inviolável só podendo ser flexibilizado por mandado judicial individualizado e fundamentado que deve ser cumprido durante o dia ou para atendimento a emergência em casos de crime flagrante ou situação de perigo público como incêndios. Esse é um direito fundamental garantido pela constituição brasileira e repetido no código civil de 2002 e é considerado um marco do estado de direito por representar um obstáculo ao poder do Estado de interferir na privacidade dos indivíduos. Porém, esse direito não é garantido à todos, pois como amplamente trabalhado, aqueles eleitos como inimigos da sociedade são sujeitos à um direito precarizado voltado a permitir o combate "ao crime”. Não analisando a questão jurídica, mas sim as implicações jusfilosóficas que tal medida demonstra assim como 
essa manifesta a presença extrema do Direito Penal do Inimigo no ordenamento jurídico nacional e a importância desse na cultura do medo vigente. Durante o período de intervenção federal na unidade federativa do Rio de Janeiro em 2018 ocorreu a utilização do chamado mandado de busca coletivo que visava a permissão para busca e apreensão e a violação do direito ao domicílio de forma a conduzir a persecução penal de traficantes e membros de organizações criminosas em comunidades do Rio de Janeiro9. Dessa forma, o mandado coletivo visava a permissão genérica e não direcionada a um determinado indivíduo, mas sim à toda uma coletividade que apenas pelo endereço domiciliar se tornam suspeitas pela atividade estadual e passíveis de terem o seu direito constitucional ao domicílio violados.

A utilização de tal mandado coletivo é extremamente discutido na academia e pela própria jurisprudência, mas ainda assim é utilizado e apresenta um dos grandes problemas que são consequência direta da teoria do Direito Penal do Inimigo, do punitivismo e do estado securitário, que também demonstra o flerte dessa teoria com o totalitarismo e como o Estado adota em larga escala essa corrente punitivista. Ao permitir um mandado de busca e apreensão genérico em uma comunidade do Rio de Janeiro, a mensagem do Estado é clara e a definição do inimigo é revelada. Ao tomar essa atitude o Estado demonstra um caráter lombrosiano que identifica nas favelas um grupo inteiro com potencial para delinquir e a possibilidade de qualquer um desses se tornar uma ameaça ao Estado apenas por morar em uma comunidade carente, ou seja, para o Estado se adquire o potencial para ser um inimigo apenas pelo endereço e por ser um inimigo em potencial não há direitos fundamentais garantidos pela constituição que todos os outros membros da sociedade possuem. Qual a porcentagem da população das comunidades no Rio de Janeiro que efetivamente são vinculados ao crime organizado? O número certamente é muito baixo e mesmo que fosse uma maioria considerável, não se justificaria a perseguição a um grupo apenas pelo seu endereço, pois demonstra o caráter totalitário do Estado e acentua os poderes

\footnotetext{
9 KADANUS, Kelli. O que é e para que serve o polêmico mandado coletivo de busca e apreensão. Gazeta do Povo, Curitiba, 20 de fev. de 2018. Disponível em: https://www.gazetadopovo.com.br/politica/republica/o-que-e-e-para-que-serve-o-polemicomandado-coletivo-de-busca-e-apreensao-95uo85ljtowyuc8es6jvobojt/ Acesso em or de dez. de 2020.
} 
extremos que são dados ao Estado ao permitir que esse defina o inimigo, ainda mais quando a escolha do Estado demonstra a hipocrisia e cegueira seletiva do mesmo.

A presunção de delinquência nas comunidades do Rio de Janeiro possui a mesma natureza do Direito Penal do Inimigo que ganhou grande força com os atentados terroristas de $200 \mathrm{I}$ nos Estados Unidos da América. No país norteamericano ocorreu a presunção de delinquência de grupos de origem religiosa islâmica e o Direito Penal do Inimigo que encontrou um berço se propagou para a américa latina:

Como a comunicação em massa alcançou o maior grau de globalização, o discurso do atual autoritarismo norte-americano é o mais difundido do mundo. Seu simplismo popularesco (volkisch) é imitado em todo o planeta por comunicadores ávidos de rating, embora tenha maior êxito na América Latina, dada a sua precariedade institucional. (ZAFFARONI, 2017, p.72)

Zaffaroni comenta o Direito Penal do Inimigo identificando perfeitamente o elemento fundante desse que é o volkisch de Schmitt, o populismo. A persecução penal das comunidades e a presunção criminosa dessa é utilizada de forma populista com fins eleitorais e ao analisar a postura do Estado frente a outros crimes - em especial os crimes de colarinho branco - se demonstra a hipocrisia do Estado. A mesma presunção de delinquência que é conferida aos moradores de comunidades carentes não é conferida à grandes executivos e aos políticos, mesmo apresentando uma porcentagem de delinquência incomparavelmente mais elevada do que a apresentada nas comunidades.

O discurso da segurança e a defesa da força punitiva hipertrofiada acaba sempre por recair naqueles considerados “inferiores” pelo establishment político, gerando perseguição aos grupos marginalizados e um direito penal subjetivo que não pune fatos, mas sim autores, independentemente do fato cometido ou da gravidade. Assim como no punitivismo do século XIX e XX, a desconfiança e a culpa pela criminalidade recaem sobre os marginalizados e a busca incansável pela segurança propagada pelo estado securitário torna esses marginalizados como indesejados da socidade, sub-humanos que apenas servem para os propósitos do estado securitário como alvo de ações policiais populistas e com fins eleitorais. O punitivismo sempre 
esteve intimamente ligado com classicismo, racismo e xenofobia, as novas roupagens do punitivismo não conseguem disfarçar as consequências reais de suas políticas.

\section{CONCLUSÃO}

A noção clássica de contratualistas defensores da segurança como razão do estado levou a um Estado que possui carta branca para atingir a esfera individual de seus cidadãos em nome da segurança. Porém, o rigor e o poderio punitivo do Estado nunca é utilizado contra aqueles que fazem parte do "nós", mas sempre contra "eles", é a institucionalização do agrupamento amigo-inimigo, a oficialização do "cidadão de bem" contra os "vagabundos", "parasitas" e "corruptos". A estilização moderna dada ao Direito Penal do Inimigo não consegue tirar o mal cheiro do punitivismo, mas escancara o direcionamento discriminatório do punitivismo que simultaneamente constrói e serve o estado securitário. Os crimes que ensejam às declarações de "guerra ao crime" não são os crimes de colarinho branco cujo a incidência de delinquência se encontra nas camadas mais altas da sociedade. $\mathrm{O}$ alvo é a população marginalizada, os indesejados das ambições puritanas e discriminatórias daqueles que

tomam o estado securitário como plataforma política e a segurança como valor supremo. A tentativa de limitar os esforços de segurança contra um inimigo a qual se justificaria o uso de poder além do permitido pelo Estado de Direito não se sustenta, pois, a própria existência do estado securitário depende da incerteza da periculosidade, ou seja, da impossibilidade de se definir o perigo que pode vir a acontecer e por isso não ter como limitar o que é ou não necessário para responder a ameaça. (ZAFFARONI, 2017, p. 162).

Por isso, o caráter vago dos discursos pautados na segurança contribui para o aumento arbitrário do poder policial em relação ao indivíduo e o Estado de Direito se coloca em perigo frente a tal cenário, tendo em vista que o punitivismo e o estado securitário imprescindem da possibilidade do soberano, do governante, definir quando é necessário ou não agir além dos limites impostos, concedendo ao soberano um poder reminiscente dos tempos das monarquias absolutistas. De forma semelhante, a definição de inimigo é também estabelecida pelo soberano, pois ele que definiria quem ameaça a existência da sociedade, podendo deter assim poder para 
perseguir inimigos políticos, sociais e culturais. Logo, o estado securitário apresentase como uma realidade que alterou as relações humanas e aumentou a sensação de medo e insegurança, sendo a segurança utilizada como ferramenta política para aumento do poder do Estado em detrimento dos direitos dos cidadãos. Quanto maior o poder punitivo for e quanto mais a segurança for considerada como valor político supremo, menor serão as liberdades individuais e pior serão as condições das camadas marginalizadas da sociedade, criando um Estado comparável às piores distopias já escritas pela literatura fictícia.

\section{REFERÊNCIAS BIBLIOGRÁFICAS}

AGAMBEN, Giorgio. De l'Etat de droit à l'Etat de sécurité. Le Monde. Paris, 2015.

ANITUA, Gabriel Ignacio. Histórias dos pensamentos criminológicos. Revan. Rio de Janeiro/RJ, 2008.

CONDE, Francisco Muñoz. Direito Penal do Inimigo. Juruá Editora. Curitiba/PR, 2012.

GAROFALO, Rafaelle. La Criminología. Editorial B de F. Buenos Aires, 2010.

HOBBES, Thomas. Leviatã ou Matéria, forma e poder de um Estado eclesiástico e civil. Martin Claret, São Paulo/SP, 2014.

LASCANO, Carlos Julio. A insustentável modernização do direito penal baseada em um direito penal para inimigos. Pensamento Penal de Sur, Buenos Aires, 2004.

LISZT, Franz Von. La idea de fin en el derecho penal. Editorial Comares. Granada, 1995.

ZAFFARONI, Eugénio Raúl. $O$ inimigo no direito penal. Pensamento criminológico. Revan, Rio de Janeiro/RJ, 2017. 